UDC621.791.01.673

\title{
INNOVATIVE MATERIALS AND TECHNOLOGIES IN THE OIL AND GAS INDUSTRY
}

\author{
Makarenko Valerii ${ }^{1}$, Manhura Andrii ${ }^{*}$, Vynnykov Yuriy ${ }^{3}$, Manhura Svitlana ${ }^{4}$ \\ ${ }^{1}$ Poltava National Technical Yuri Kondratyuk University https://orcid.org/0000-0001-9178-9657 \\ ${ }^{2}$ Poltava National Technical Yuri Kondratyuk University https://orcid.org/0000-0002-4113-1870 \\ ${ }^{3}$ Poltava National Technical Yuri Kondratyuk University https://orcid.org/0000-0003-2164-9936 \\ ${ }^{4}$ Poltava National Technical Yuri Kondratyuk University https://orcid.org/0000-0002-7017-7317 \\ *Corresponding author E-mail: mangura2000@gmail.com
}

During the exploitation of equipment and piping systems of sulfuric acid, shale, metallurgical, mining, energy and other industries, the metal of a number of structures directly contacts with sulfur-containing agents at high temperatures. This results in intense corrosion, loosening and saturation of the surface layer of metal with sulfur (elementalor in the form of various compounds, including sulfides, iron, oxides) with a concentration of up to $0.6 \%$. Repair welding of such metal at its partial replacement is connected with the big labor costs caused by necessity of mechanical removal of a surface layer, as without this operation in weld metal by standard electrodes hot cracks, pores and notfusion are formed.

Keywords: corrosion, hot cracks, pores, slag, seam.

\section{ІННОВАЦЙНІ МАТЕРІАЛИ ТА ТЕХНОЛОГЇ̈ В НАФТОГАЗОВІЙ ПРОМИСЛОВОСТІ}

\author{
Макаренко В.Д., ${ }^{1}$ Мангура А.М., ${ }^{2 *}$ Винников Ю.Л., ${ }^{3}$ Мангура С.I. ${ }^{4}$ \\ 1, 2, 3,4 Полтавський національний технічний університет імені Юрія Кондратюка \\ *Адреса для листування E-mail: mangura2000@gmail.com
}

\begin{abstract}
Під час експлуатації обладнання та трубних систем сірчаної кислоти сланцевої, металургійної, гірничої, енергетичної й інших галузей промисловості метал ряду конструкцій безпосередньо контактує із сірковмісними агентами при високих температурах. Це призводить до інтенсивної корозії, розпушування та насичення поверхневого шару металу сіркою (елемента у вигляді різних сполук, у тому числі сульфідів, заліза, оксидів) з концентрацією до 0,6\%. Ремонт не зварювання такого металу при його частковій заміні пов'язане з великими витратами праці, зумовленими необхідністю механічного видалення поверхневого шару, оскільки без цієї операції зварювання стандартними електродами в металі утворюються гарячі тріщини, пори і нерозплавлення. Досліджено та розроблено прогресивні зварювальні електроди на основі нових металургійних та технологічних принципів забезпечення високої стійкості зварювальних та монтажних з'єднань проти утворення гарячих тріщин у металі зварного шва. Розроблені інноваційні електроди марки ANM-1 дозволяють зварювати металеві конструкції з низьковуглецевих сталей з поверхневим насиченням сіркою за наявності накипу, іржі та інших домішок. Вони вирізняються високою стійкістю до утворення гарячих тріщин, свищів і пор у шві. Електроди були успішно випробувані на багатьох підприємствах, пов'язаних $з$ переробкою сірковмісних матеріалів (руди, сланці, нафтопродукти, природний газ тощо). При проведенні наукових досліджень було використано високоточне сучасне обладнання, зокрема, для вивчення зварювальнихі технологічних властивостей, залучена інформаційно-аналітична система моделі АНП-2; автоматичний зварювальний апарат зі штучними електродами; сучасні інверторні випрямлячі виробництва Інституту електричного зварювання НАНУ імені Е.О. Патона, а також для оцінки якості зварних швів використовував аналізатори-контролери власної конструкції. Використання електродів ANM-1 дозволяє значно підвищити ефективність ремонтних робіт за рахунок усунення трудомістких операцій видувки повітряної дуги та подальшого очищення країв монтажного з'єднання шліфувальною машиною.
\end{abstract}

Ключові слова: корозія, гарячі тріщини, пори, шлам, шов. 


\section{Introduction}

Ukraine is one of the most technologically advanced countries in the world, which has its own oil and gas, oil refining, metallurgical industry, developed enterprises for energy production and energy supply. A prerequisite for the successful functioning of these major industries is the constant creation and updating of suitable pipe and electrode materials, as well as welding and assembly technologies, which provides these industries with competitiveness in the world market and satisfies internal needs, which in turn provides energy independence of Ukraine.

\section{Review of the research sources and publications}

During the operation of technological equipment and metal structures in chemical-aggressive environments, the metal directly contacts with sulfur-containing agents at high temperatures. This leads to intense corrosion, loosening and saturation of the surface layer of metal with sulfur (elemental or in the form of various compounds, including iron sulphides, oxides) with a concentration of up to $0.6 \%[1-8]$.

Repair by welding such metal structures in their partial replacement is associated with large labor costs, which are caused by the need for mechanical removal of the surface layer, because without such operations in the weld metal, standard welding electrodes produce hot cracks and other unacceptable defects [4-8].

Therefore, the existing traditional electrode materials and technologies of their use already significantly limit the advanced design and technical and technological opinion regarding the repair of equipment and pipeline networks of long-term exploitation in corrosive-aggressive environments, so to further improve them with a new need characteristics of the required properties [28].

\section{Definition of unsolved aspects of the problem}

Research and development of progressive welding electrodes on the basis of new metallurgical and technological principles of ensuring high resistance of welding and assembly joints against the formation of hot cracks in the weld metal.

\section{Problem statement}

The basic scientific idea is that the reason for the destruction of welding joints of oil and gas pipelines and other metal structures of long-term operation, whose surface layer of metal is saturated with sulfur (up to 0.1 $-0.6 \%$ ), is the low resistance of weld metal in the formation of hot cracks in the process of cracking cracks are formed in the process of repair welding, which makes it impossible to exploite the repaired metal structures further, as this can lead to further destruction. Therefore, the idea of providing high fracture toughness during repair welding of long-life metal structures, the surface layer of which is saturated with sulfur, is used in the electrode coating instead of ferroalloys, in particular ferromanganese, manganese metal.

\section{Research methodology}

In conducting systematic and complex scientific researches, high-precision modern equipment was used, in particular, for the study of welding and technological properties, the information-analytical system of the ANP-2 model was involved [7]; automatic welding machine with artificial electrodes; modern inverter rectifiers manufactured by the Institute of Electric Welding of NASU named after E.O. Paton, as well as to assess the quality of welds, used analyzers-controllers of their own design. For experiments, electrodes with variable manganese content of metal in the coating (from 0 to $30 \%$ ) were prepared - the rest of the coating composition is as follows (in \%): ilmenite - 50; muscovite mica -8 ; quartz sand -10 ; cellulose -2 . Supplemented the coating composition to $100 \%$, introducing iron powder from 0 to $30 \%$. The binder was $25 \%$ sodium liquid glass, density $1.55 \mathrm{~g} / \mathrm{cm}^{3}$, with module 2.76 .

\section{Basic material and results}

The doping of weld metal with manganese was carried out not through the electrode wire, but through the electrode coating, which provided less burnout in the welding process and stable doping and modification of the weld metal structure. This has provided resistance to hot cracking, since manganese metal is able to more effectively bind sulfur into a chemical-resistant compound that is insoluble in molten metal and removes it into the slag.

It is seen that the increase in the content of manganese in the coating greatly reduces the concentration of sulfur in the weld metal, in particular more than $10-20$ times, and dramatically decreases the corrosion rate, regardless of the service life of structural steel on average $2-4$ times.

Given the large volume of experimental material that characterizes the often uncertainty and contradiction of information regarding the effect of sulfur and manganese on the corrosion behavior of steels obtained by traditional methods, we have for the first time used an alternative method of experimental results analysis based on the use of artificial neural networks (SNM). The use of SNM allows to create qualitatively new hardware and software, which significantly extend the classes of tasks to be solved and increase the efficiency of analysis and forecasting [7].

Using a neural network simulation method, we obtained a predictive model of weld behavior performed on grade 3 low carbon steel in corrosive environment.

The results of experimental studies of the effect of metal manganese on the corrosion rate and the sulfur content of the weld metal are presented in Fig. 1 - 2 .

Fig. 2 shows the simultaneous joint effect of the sulfur content in the weld metal and the manganese metal in the electrode coating on the corrosion rate of the samples. At the same time, it can be argued that the content of manganese in the coating in the range of $23-25 \%$ significantly reduces the tendency of weld metal to corrosion. This made it possible to optimize the content of manganese metal, which is introduced into the coating in the form of powder, limiting it to a range of $22-25 \%$. 
For example, for steel with a lifetime of 20 years, the initial sulfur content in the surface layer of metal (up to $1 \mathrm{~mm}$ ) was about $0.52 \%$, then the introduction of $20-$ $25 \%$ in the coating of manganese metal allowed to reduce the sulfur content in the weld metal to $0.03-$ $0.045 \%$ that is, $12.6-17.3$ times.

Using the neural network method of analysis of the obtained experimental results, a spatial model of simultaneous influence of the sulfur content in the surface layers of the metal of equipment (decomposers) and manganese metal in the electrode coating was constructed with different terms of exploitation in an aggressive environment (Fig. 2).

a)

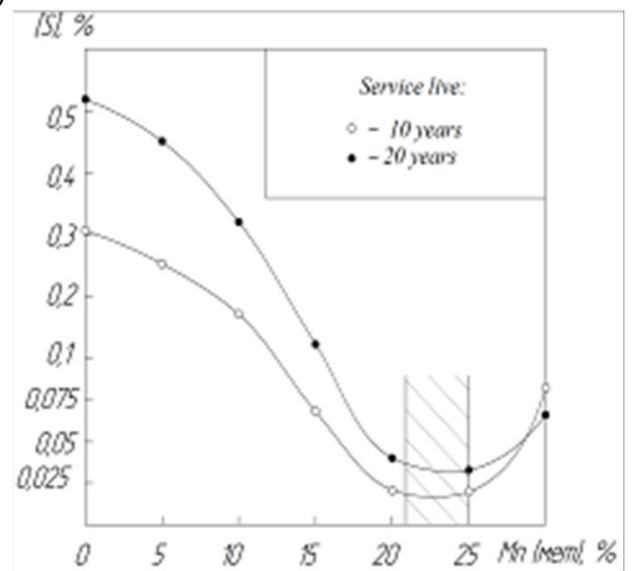

The influence of manganese metal on the resistance of weld metal against the formation of hot cracks. The tendency of electrodes to form hot cracks was quantitatively evaluated according to the method of MVTU named after M.V. Bauman after on the LTP-1-6M installation [8]. The criterion of the resistance of the weld metal to the formation of hot cracks during welding was the indicator A $(\mathrm{mm} / \mathrm{min})$, which characterizes the minimum value of the rate of deformation at which the formation of hot cracks can be seen. Welding was performed on alternating current in modes: $\mathrm{I}_{\mathrm{zv}}=180 \mathrm{~A}, \mathrm{U}_{\mathrm{d}}=22-24 \mathrm{~V}, \mathrm{~V}_{\mathrm{zv}}=14 \mathrm{~m} / \mathrm{h}$. The results of the studies are shown in Fig. $3-5$.

b)

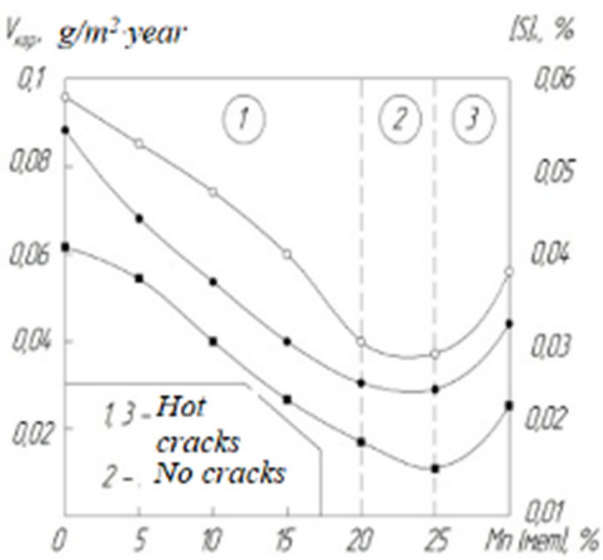

Figure 1 - Effect of manganese in the electrode coating on the sulfur content of the weld metal (a) and on the corrosion rate of the weld joints (b) of the low carbon steel hull grade VSt3sp decomposers lasted for a long time. Designation (b):

$\mathrm{o}$ - steel has been used for 18 years (in the surface layer up to $1 \mathrm{~mm}$ deep, sulfur content was $\approx 0.45 \%$ ); - -14 years respectively $([\mathrm{S}] \approx 0.32 \%) ; \boldsymbol{\square}-8$ years respectively $([\mathrm{S}] \approx 0.25 \%)$

a)

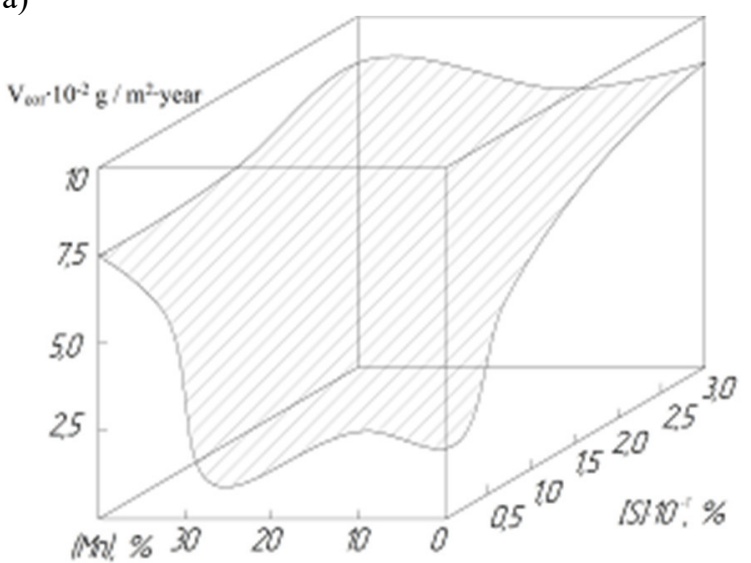

b)

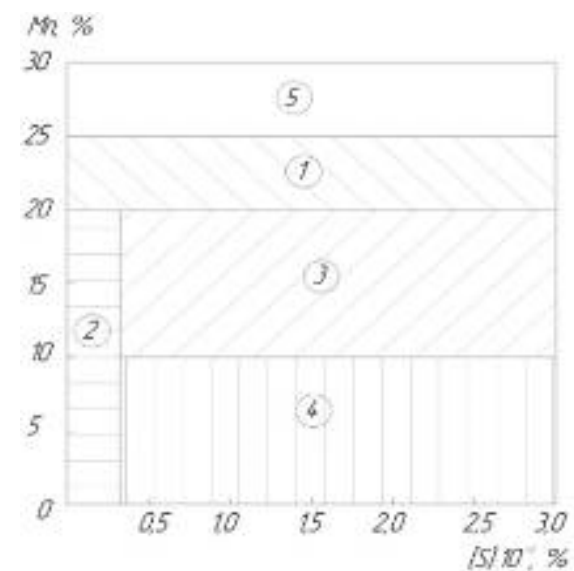

Figure 2 - Neural network analysis of corrosion rate of weld metal samples

in corrosive-aggressive model environment $\mathrm{NACE}$ with different content of manganese metal in the electrode coating and concentration dissolved in sulfur metal (a) and predicted by SNM of stability in hot welds made on low carbon steel Vst3sp with different content in the surface layers of sulfur by electrodes ANM-1 with different content of manganese metal in the coating:

1 - areas of high resistance to hot cracks; 2 - area of variable stability; 3 - area of low stability; $4-$ is an area of very low resistance; 5 - is an area of unstable stability 

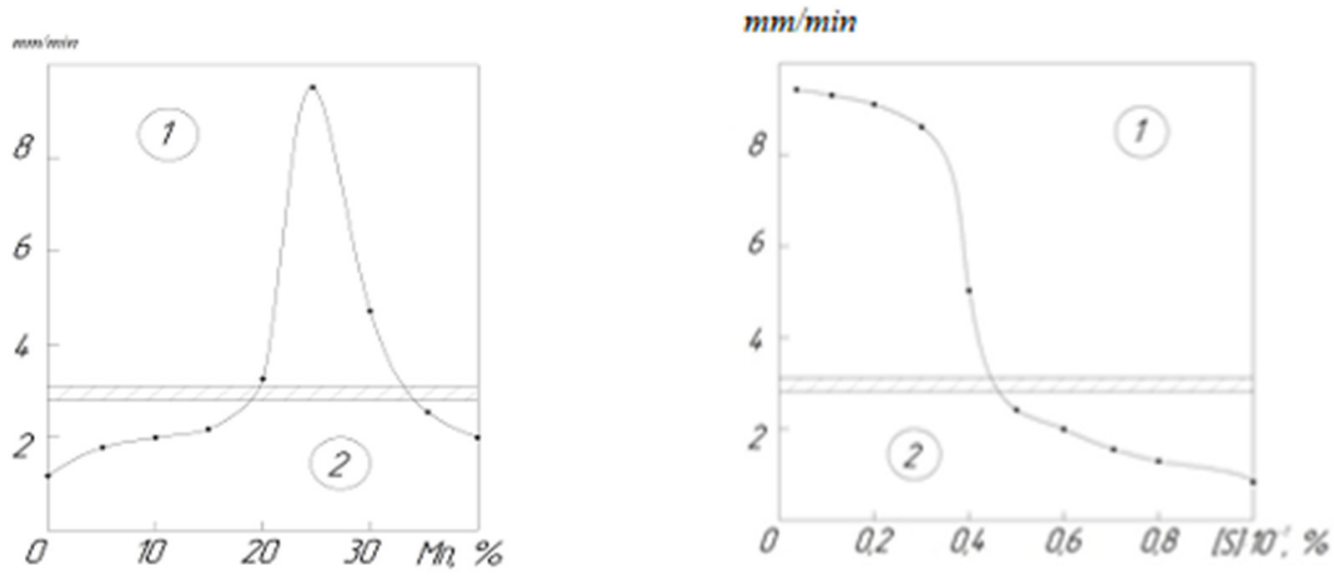

Figure 3 - Effect of the manganese content of metal (a) in the electrode coating and sulfur in the weld metal (b) on the resistance against the formation of hot cracks in the welds

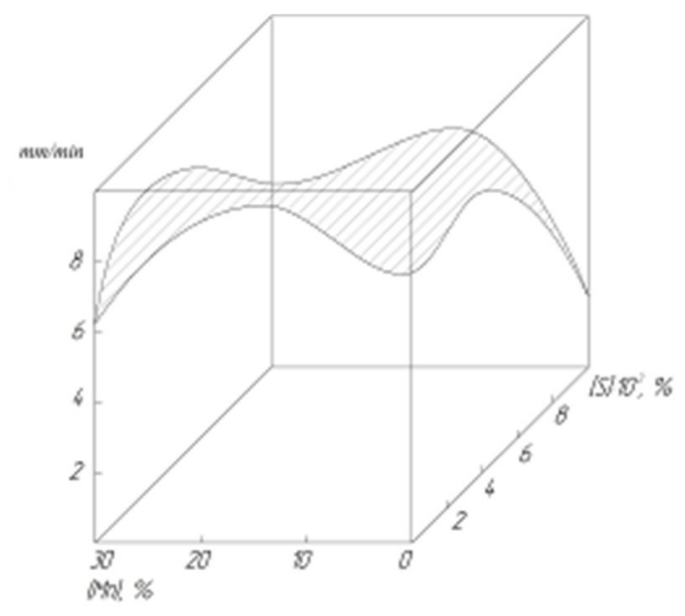

Figure 4 - Three-dimensional model of resistance to hot crack formation in welds, depending on the content of manganese metal in the electrode coating and the concentration of dissolved sulfur in the surface layers of metal long-term operation in corrosive environment

Analysis of the data shows that the introduction into the electrode coating of manganese metal in the amount of $20-30 \%$ significantly increases ( $4-5$ times) resistance to the formation of hot cracks. In the opposite way, the content in the deposited metal of sulfur influences the formation of hot cracks. Thus, when the sulfur content of $0.042 \%$ or more sharply reduces the resistance of the metal against the formation of hot cracks.

The above data are processed by mathematical modeling methods, the results of which are shown in a three-dimensional model (Fig. 4). Obviously, in spatial form, areas of high and low resistance to the formation of hot cracks during welding are visible.

Figure 5 presents a profile of a welded joint made by ilmenite electrodes of the ANM-1 brand. It is seen that the weld seam is cleared of sulfur and her content does not exceed $0.04-0.05 \%$, that is, the reduction of sulfur

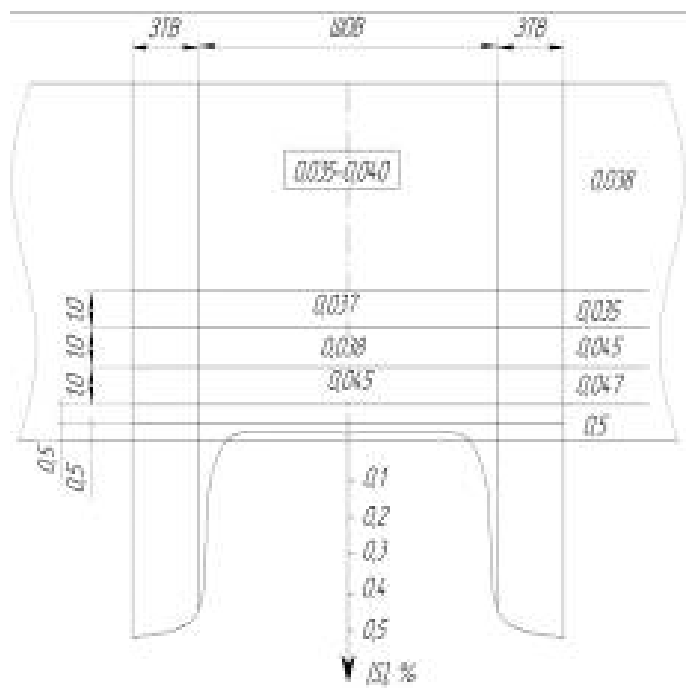

Figure 5 - Profile of welding joint made

by ANM-1 electrode on low carbon steel with different sulfur content in the surface layer

content occurs more than 10 times, which allows guaranteed to increase the resistance of the weld metal against the formation of hot cracks in the process of welding contaminated with sulfur metal.

The influence of the content of manganese metal in the coating on the separation of the slag crust from the surface of the deposited metal. The results of measurements of the index of separability of the slag crust from the surface of single-layer welds are shown in Fig. 6.

From the data shown in Fig. 6 it can be seen that the lightest separability of the slag from the surface of the weld metal is characterized by electrodes which place in their composition metal manganese in the range of $20-30 \%$.

Thus, the obtained results were taken into account in the development of new electrode coatings in order to improve welding and technological properties. 


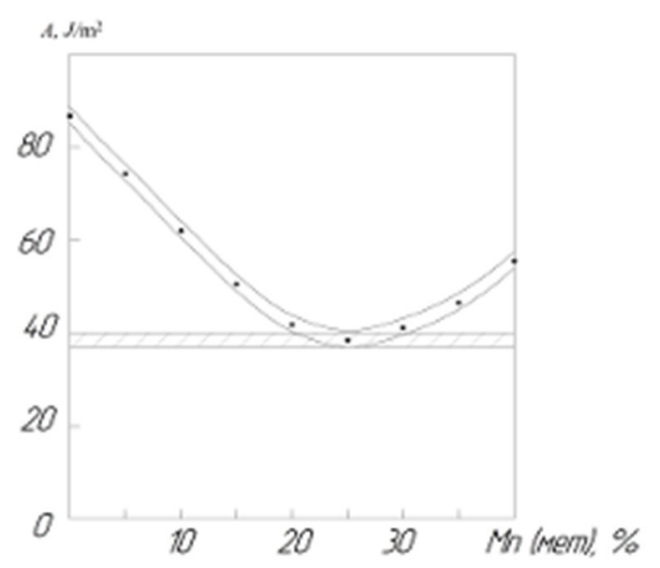

Figure 6 - Effect of metallic manganese content in the electrode coating on the index of separability of slag crust from the surface of welds

The results of quantitative assessment of the tendency of welds against the formation of hot cracks for different brands of electrodes are shown in Table 1.

Table 1 - Results of quantitative assessment of the tendency of welds against the formation of hot cracks for different brands of electrodes are shown

\begin{tabular}{|l|c|c|}
\hline $\begin{array}{c}\text { Electrode } \\
\text { Brand }\end{array}$ & $\begin{array}{c}\text { The main metal, } \\
\text { thickness, } \mathrm{mm}\end{array}$ & $\mathrm{A}, \mathrm{mm} / \mathrm{min}$ \\
\hline ANM-1 & & 9.82 \\
UONI-1355 & VSt3sp, 16 & 4.30 \\
ANO-11 & 4.64 \\
\hline \multicolumn{2}{|l|}{ critical value of the indicator A $-3-3.5 \mathrm{~mm} / \mathrm{min}$} \\
\hline
\end{tabular}

Considering that the critical value of indicator $\mathrm{A}$ for structural steels is $3-35 \mathrm{~mm} / \mathrm{min}$, high resistance to the formation of hot cracks in the joints made by new electrodes (ANM-1) is noteworthy.

Table 2 shows the characteristics of the stability of the combustion of an electric arc AC and the transfer of molten metal across the electrode gap. Indicators $B_{z}$ and $\tau_{\mathrm{z}}$ were determined using the ANP- 1 model measurement and information system «Non-stationary Process Analyzer»».

Table 2 shows that the ANM-1 electrodes are characterized by high arc burning stability and small-drop transfer of electrode metal. In particular, the stability index of the developed electrodes is almost 3 times higher than the ANO-11 electrodes intended for AC welding.

The results of measurements of the stability of the combustion of the $\operatorname{arc}\left(\mathrm{V}_{\mathrm{z}}, \mathrm{Om}^{-1} \cdot \mathrm{s}^{-1}\right)$ and the duration of short circuits $(\tau \mathrm{kz}, \mathrm{ms})$. Electrodes with a diameter of $4 \mathrm{~mm}$.

Experimental and industrial testing. The chemical composition of the weld metal (ANM-1) is typical of electrodes of the E46 type, but differs in the lower content of harmful impurities (in\%): $\mathrm{C}-0.08$; $\mathrm{Mn}-0.8-1.2 ; \mathrm{Si}-0.15-0.20 ; \mathrm{S} \leq 0.025 ; \mathrm{P} \leq 0.025$.
The values of the impact toughness of the weld metal made by the ANM-1 electrodes on VSt3sp steel are given in Table 3.

Table 2 - Stability index of the developed electrode

\begin{tabular}{|l|c|l|}
\hline \multirow{2}{*}{ Electrode Brand } & $180 \mathrm{~A}$ & $110 \mathrm{~A}$ \\
\cline { 2 - 3 } & $\mathrm{B}_{3}, \mathrm{Om}^{-1} \cdot \mathrm{s}^{-1}$ & $\tau_{\mathrm{к} 3}, \mathrm{~ms}$ \\
\hline ANM-1 & 312.4 & 9.6 \\
Ferex & 126.1 & 16.7 \\
Schwarz 3K & 120.4 & 17.7 \\
OK48.23 & 143.4 & 17.5 \\
UONI-13/55 & 76.4 & 16.6 \\
ANO-4 & 321.2 & 9.9 \\
\hline
\end{tabular}

Table 3 - The values of the impact toughness of the weld metal made by the ANM-1 electrodes on VSt3sp steel

\begin{tabular}{|c|c|c|c|c|}
\hline \multirow{2}{*}{$\begin{array}{l}\text { Electrode } \\
\text { Brand }\end{array}$} & \multirow{2}{*}{$\begin{array}{l}\text { Brand and } \\
\text { thickness of } \\
\text { the steel, } \\
\text { mm }\end{array}$} & & & \\
\hline & & +20 & -20 & -40 \\
\hline ANM-1 & VSt3sp,16 & $\begin{array}{l}100- \\
113\end{array}$ & $\begin{array}{l}70- \\
83\end{array}$ & $\begin{array}{l}43- \\
56\end{array}$ \\
\hline
\end{tabular}

Analysis of the data in Table 3 shows that the ANM1 electrodes provide the toughness of the weld metal of low carbon steels, which meets the requirements for the type of electrodes E46 according to GOST 9457-75.

Tests for sulfide cracking electrodes were performed according to the method of the International Corrosion Association according to NACE standard TM-01-77 (90) [8]. The basic test time is 680 hours. The results are shown in Table 4, which shows that the electrodes ANM-1 are characterized by high resistance to sulfide corrosion cracking on steel VST3sp in comparison with the best foreign electrodes in particular known manufacturers of welding materials - Japan and Sweden.

The impact toughness of the weld $\mathrm{KSV}\left(\mathrm{J} / \mathrm{cm}^{2}\right)$ at temperature, ${ }^{\circ} \mathrm{C}$.

Table 4 - Electrodes ANM-1 are characterized by high resistance to sulfide corrosion cracking on steel VST3sp

\begin{tabular}{|l|l|l|}
\hline \multirow{2}{*}{$\begin{array}{l}\text { Electrode } \\
\text { Brand }\end{array}$} & \multirow{2}{*}{$\begin{array}{l}\text { Factory (firm), } \\
\text { country }\end{array}$} & $\mathrm{A},\left(\mathrm{J} / \mathrm{cm}^{2}\right)$ \\
\cline { 3 - 3 } & $\begin{array}{l}\text { EEZ named after } \\
\text { E.O. Paton }\end{array}$ & 6.8 \\
\hline AHM-1 & ESAB, Sweden & 5.2 \\
\hline OK74.78 & Romania & 4.9 \\
\hline Nibaz 65 & Germany & 4.4 \\
\hline 461SHV1 & $\begin{array}{l}\text { Vamberk, } \\
\text { Czech Republic }\end{array}$ & 3.8 \\
\hline E-B235 & $\begin{array}{l}\text { Kobe Steel, } \\
\text { Japan }\end{array}$ & 5.7 \\
\hline E8016-C1 &
\end{tabular}

Figure 7 shows the comparative results of the corrosion rate measurements of welds of ilmenite electrodes 
grades ANM-1 and ANO-6 made on steel grade BC3sp with different sulfur content in the surface layers (metal fragments were cut from decomposers intended for alumina production, with different service life). It is seen that the weld metal of the new ANM-1 electrodes has a $2-4$ times lower corrosion rate than the known ilmenite electrodes ANO-6, especially manifested at high concentrations of sulfur in the surface layers of metal of equipment of long-term exploitation (more than 15 years).

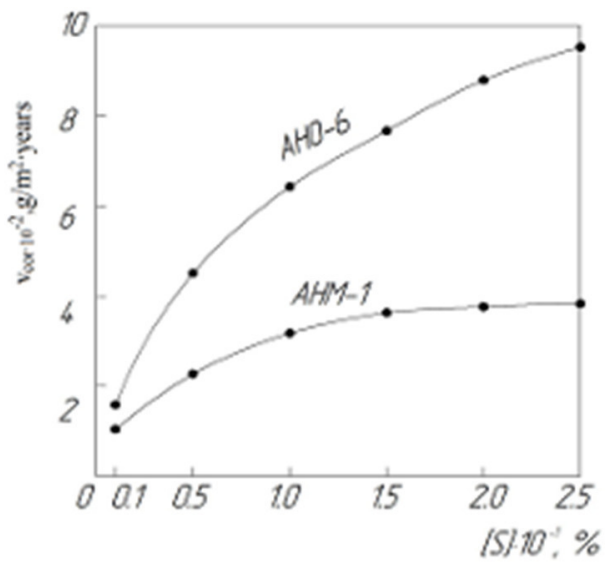

Figure 7 - Corrosion rate of welds on steels with different service life in aggressive media with new electrodes compared to ilmenite electrodes ANO-6

The new ANM-1 electrodes have been successfully passed extensive industrial testing at a number of Ukrainian enterprises and organizations, in particular: SE «Research Plant of Welding Materials Electric Welding Institute of NAS Unamed after E.O. Paton» (Kyiv); PE «PromtruboProvodKomplekt» (Boyarka); PE «METCON» (Kiev); PE «Engineering Center of Welding and Surfacing Materials» (Kiev); PC «Center of Construction and Installation Works and Operations of Buildings and Structures» of PC «Ukrza» (Mariupol); LLC «Azovmashprom» (Mariupol); JSC «Azovzagalmash» (Mariupol); RPE «Naftogazservice» (Gadjach, Poltava region) and others.
The ANM-1 electrodes were tested in a laboratory accredited by the State Standard of Ukraine (accreditation certificate No. 131 of 29.07.1994). The necessary technical documentation (technological instructions for production, specifications, etc.) has been developed for the ANM-1 electrodes.

More than 100 tons of ANM-1 electrodes were manufactured; implemented at 15 enterprises; UAH 250 million was received; economic effect; 245 new jobs were created; 10 License agreements with enterprises were signed; it is planned to create another 50 new jobs and receive 50 million UAH. economic effect.

\section{Conclusions}

During the exploitation of the equipment and pipeline systems of sulfuric acid, shale, metallurgical, mining, energy and other industries, the metal of a number of structures directly contacts with sulfur-containing agents at high temperatures. This leads to intense corrosion, loosening and saturation of the surface layer of metal with sulfur (elemental or in the form of various compounds, including iron sulphides, ox sulfides) with a concentration of up to $0.6 \%$. Repair welding of such metal at its partial replacement is connected with the big labor costs caused by necessity of mechanical removal of a surface layer, as without this operation in weld metal by standard electrodes hot cracks, pores and not fusion are formed. Developed innovative electrodes of the ANM-1 brand allow to weld metal structures from low carbon steels with surface saturation with sulfur, in the presence of scale and rust and other impurities. They are highly resistant to the formation of hot cracks, fistulas and pores in the weld. The electrodes have been successfully tested extensively by many enterprises involved in the processing of sulfur-containing materials (ores, shales, petroleum products, natural gas, etc.). The use of ANM-1 electrodes can significantly improve the efficiency of repair work by eliminating the time-consuming operations of aft-arc gouging and subsequent cleaning of the edges of the mounting joint with a grinding machine.

\section{References}

1. Макаренко, В.Д., Чеботар, I.М., Петренко, О.О., Ногіна, А.М. (2019). Дослідження механічних властивостей труб охолоджуючих систем довготривалої експлуатації в широкому інтервалі мінусових температур в умовах бродильного виробництва. Проблеми тертя та зношення, 1(82), $69-77$.

http://dx.doi.org/10.18372/0370-2197.1(82).13489

2. Kharchenko, M., Manhura, A., Manhura, S. \& Lartseva, I. (2017). Analysis of magnetic treat-ment of production fluid with high content of asphalt-resin-paraffin deposits. Journal Mining of Mineral Deposits, 11-2, 28-33

http://ir.nmu.org.ua/handle/123456789/149572

3. Vynnykov, Yu.L., Makarenko, V.D., Kravets, I.A. \& Mynenko, I.S. (2019). Doslidzhennia prychyn znyzhennia mitsnosti truboprovodiv TETs. Problemy tertia ta znoshennia, 1(82), 63-68.

http://dx.doi.org/10.18372/0370-2197.1(82).13488
1.Makarenko V.D., Chebotar I.M., Petrenko O.O., \& Nohina A.M. (2019) Doslidzhennia mekhanichnykh vlastyvostei trub okholodzhuiuchykh system dovhotryvaloi ekspluatatsii v shyrokomu intervali minusovykh temperatur v umovakh brodylnoho vyrob-nytstva Problemy tertia ta znoshennia., №1(82), S. 69 - 77.

http://dx.doi.org/10.18372/0370-2197.1(82).13489

2. Kharchenko, M., Manhura, A., Manhura, S. \& Lartseva, I. (2017). Analysis of magnetic treat-ment of production fluid with high content of asphalt-resin-paraffin deposits. Journal Mining of Mineral Deposits, 11-2, 28-33

http://ir.nmu.org.ua/handle/123456789/149572

3. Vynnykov, Yu.L., Makarenko, V.D., Kravets, I.A. \& Mynenko, I.S. (2019). Doslidzhennia prychyn znyzhennia mitsnosti truboprovodiv TETs. Problemy tertia ta znoshennia, 1(82), 63-68.

http://dx.doi.org/10.18372/0370-2197.1(82).13488 
4. Vynnykov, Yu., Manhura, A., Zimin, O. \& Matviienko, A. (2019). Use of thermal-magnetic devices for prevention of asphaltene, resin, wax deposits on oil equipment surfaces. Journal Mining of Mineral Deposits, 13-2, 34-40 https://doi.org/10.33271/mining13.02.034

5. Онищенко, В.О., Винников, Ю.Л., Зоценко, М.Л., Пічугін, С.Ф., Харченко, М.О., Степова, О.В., Савик, В.М., Молчанов, П.О., Винников, П.Ю., Ганошенко, О.М. (2018). Ефективні конструктивно-технологічні рішення об'єктів транспортування нафти $і$ нафтопродуктів у складних інженерно-геологічних умовах. Полтава: ФОП Пусан.

6. DIN EN 12007-1:2012-10. (2012). Gas infrastructurePipelines for maximum operating pressure up to and including 16 bar - P. 1: General functional requirements; German version EN 12007-1:2012, Germany.

7. Вовк, О.В. та ін. (2017). Аналіз аварій на магістральних трубопроводах за період 2005-2015 рр. Енергетика: економіка, технології, екологія, 4, 113 - 118.

8. Ellenberger, J.P. (2014). Piping and Pipeline Calculations Manual. Construction, Design Fabrication and Examination. USA: Oxford: Elsevier.
4. Vynnykov, Yu., Manhura, A., Zimin, O. \& Matviienko, A. (2019). Use of thermal-magnetic devices for prevention of asphaltene, resin, wax deposits on oil equipment surfaces. Journal Mining of Mineral Deposits, 13-2, 34-40

https://doi.org/10.33271/mining13.02.034

5. Onyshchenko, V.O., Vynnykov, Yu.L., Zotsenko, M.L., Pichuhin, S.F., Kharchenko, M.O., Stepova, O.V., Savyk, V.M., Molchanov, P.O., Vynnykov, P.Iu. \& Hanoshenko, O.M. (2018). Effective structural and technological solutions of oil and petroleum products transportation facilities in difficult engineering-geological conditions. Poltava: IE Pusan.

6. DIN EN 12007-1:2012-10. (2012). Gas infrastructure Pipelines for maximum operating pressure up to and including 16 bar - P. 1: General functional requirements; German version EN 12007-1:2012, Germany.

7. Vovk, O.V. et. al. (2017). Analysis of accidents at main pipelines for the period 2005-2015 Energy: economics, technologies, ecology, 4, $113-118$.

8. Ellenberger, J.P. (2014). Piping and Pipeline Calculations Manual. Construction, Design Fabrication and Examination. USA: Oxford: Elsevier. 